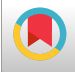

\title{
Elimination and Control of Viral Hepatitis B and C Infections Possible With Greater Attention to High Risk Groups \\ Seyed Moayed Alavian ${ }^{1, *}$
}

${ }^{1}$ M.D, Professor of Medicine, Baqiyatallah Research Center for Gastroenterology and Liver Diseases, Baqiyatallah University of Medical Sciences, Director of Iran Hepatitis Network, Tehran, IR Iran

"Corresponding author: Seyed Moayed Alavian, M.D, Professor of Medicine, Baqiyatallah Research Center for Gastroenterology and Liver Diseases, Baqiyatallah University of Medical Sciences, Director of Iran Hepatitis Network, Tehran, IR Iran. Tel/Fax: +98-21889451867-8, E-mail: alavian@thc.ir

Received 2017 August 30; Accepted 2017 September 10.

Keywords: Hepatitis C, Epidemiology, Risk Factor

Hepatitis B virus (HBV) and hepatitis C virus (HCV) infections are the main causes of chronic live diseases and mortality related to viral infections around world (1). Today, with new and effective drugs for the treatment of HCV infection, elimination is possible and the main barrier for this goal is identifying infected subjects. Due to the lack of symptoms until advanced stages, most infected patients are undiagnosed (2). Blood and blood products transfusion before the time of screening for HCV (in Iran before 1996) (3), and intravenous drug abuse (4-6) are the main risk factors for HCV infection in Iran and other parts of the world. It is necessary for health policy makers to design effective screening programs to identify HCV-infected subjects through review of the main risk factors, yet they should not forget the neglected risk factors. Hemophilia, thalassemia, and patients on hemodialysis are in greater contact with HCV infection and the highest prevalence of HCV has been reported in patients with hemophilia. Screening and therapy of all HCV-infected cases in these groups is possible and elimination is currently achievable.

Sexual transmission of HCV may occur, yet the rate is not as high as hepatitis B virus (HBV) and HIV infections (7). The rate of transmission is greater in sexual promiscuity or prostitution (8). Non-sexual contact with an HCVinfected subject in a family due to sharing shaving devices should be attended by future case studies. Other risk factors, such as hospitalization (7, 9), surgical procedures (9), high-risk jobs, such as health care workers (10), cutting the head in Ashura, Garbage collectors, history of unsafe injection practices, being homeless, and history of imprisonment are other risk factors for HCV infection. There is controversy regarding contact with sportsmen and acquiring HCV (11), yet it is recommended to perform more studies with higher number of samples for better understanding of the subject. Shared steroid syringes, contact with blood in judo, wrestling and boxing may place individuals at a higher risk.

It seems that population-based and case-control studies are required to determine special risk factors related to each area around the world.

\section{References}

1. Hesamizadeh K, Sharafi H, Rezaee-Zavareh MS, Behnava B, Alavian SM. Next Steps Toward Eradication of Hepatitis C in the Era of Direct Acting Antivirals. Hepat Mon. 2016;16(4). e37089. doi: 10.5812/hepatmon.37089. [PubMed: 27275164].

2. Zare F, Fattahi MR, Sepehrimanesh M, Safarpour AR. Economic Burden of Hepatitis C Virus Infection in Different Stages of Disease: A Report From Southern Iran. Hepat Mon. 2016;16(4). e32654. doi: 10.5812/hepatmon.32654. [PubMed: 27257424].

3. Alavian SM, Gholami B, Masarrat S. Hepatitis C risk factors in Iranian volunteer blood donors: a case-control study. J Gastroenterol Hepatol. 2002;17(10):1092-7. [PubMed: 12201870].

4. Graham S, Harrod ME, Iversen J, Simone Hocking J. Prevalence of Hepatitis C Among Australian Aboriginal and Torres Strait Islander people: A Systematic Review and Meta-Analysis. Hepat Mon. 2016;16(7). e38640. doi: 10.5812/hepatmon.38640. [PubMed: 27651805].

5. Onyekwere CA, O. Ogbera A, Olusola Dada A, O. Adeleye O, O. Dosunmu A, Akinbami AA, et al. Hepatitis C Virus (HCV) Prevalence in Special Populations and Associated Risk Factors: A Report From a Tertiary Hospital. Hepat Mon. 2016;16(5). e35532. doi: 10.5812/hepatmon.35532. [PubMed: 27313634].

6. Woltmann J, Burke P, Brady R, Blackard JT. Demographics of Hepatitis C in Southwest Ohio (2010 to 2015). Hepat Mon. 2016;16(8). e37904. doi: 10.5812/hepatmon.37904. [PubMed: 27799964].

7. Shev S, Hermodsson S, Lindholm A, Malm E, Widell A, Norkrans G. Risk factor exposure among hepatitis $C$ virus RNA positive Swedish blood donors-the role of parenteral and sexual transmission. Scand J Infect Dis. 1995;27(2):99-104. [PubMed: 7544914].

8. Jahani MR, Alavian SM, Shirzad H, Kabir A, Hajarizadeh B. Distribution and risk factors of hepatitis B, hepatitis C, and HIV infection in a female population with "illegal social behaviour". Sex Transm Infect. 2005;81(2):185. doi: 10.1136/sti.2004.011114. [PubMed: 15800109]. 
9. Gaeta GB, Stroffolini T, Taliani G, Ippolito FM, Giusti G, De Bac C. Surgical procedures as a major risk factor for chronic hepatitis $\mathrm{C}$ virus infection in Italy: evidence from a case-control study. Int J Infect Dis. 1999;3(4):207-10. [PubMed: 10575150].

10. Neal KR, Jones DA, Killey D, James V. Risk factors for hepatitis C virus infection. A case-control study of blood donors in the Trent Region
(UK). Epidemiol Infect. 1994;112(3):595-601. [PubMed: 8005225].

11. Sorouri R, Hakami Zanjani M, Hajkarim B, Mousavinasab N, Noori M, Sobhani V. Prevalence of Hepatitis B, Hepatitis C and HIV and Related Risk Factors in Contact Sportsmen in Zanjan: A Letter to Editor. HepatMon.2015;15(10).e32818. doi: 10.5812/hepatmon.32818. [PubMed: 26587042]. 